\title{
Policy priorities in diabetes care: a Delphi study
}

\author{
Morris Gallagher, Colin Bradshaw, Helen Nattress
}

\begin{abstract}
Objectives-To produce policy priorities for improving care of diabetes based on the findings of original research into patient and professional opinions of diabetes care in South Tyneside. To judge the feasibility of implementing these priorities as policy.

Design-A two round Delphi survey with a panel of 28 "experts." In the first round each respondent produced a list of recommendations based on the findings of a report of patients' and professionals' opinions of diabetes care. 20 respondents produced a total of 180 recommendations, reviewed by a monitoring panel to produce a summary list of 28 recommendations. In the second round respondents rated each recommendation on two 5 point Likert scales.
\end{abstract}

Setting-Mainly Tyneside but also other parts of England.

Subjects-28 healthcare professionals, including patients and patients' representatives.

Main measures-Voting by experts on how important each recommendation was to improving diabetes care service, and how likely the recommendation was to be implemented in the next five years.

Results-There was a high degree of consensus among respondents about recommendations considered important and likely to be implemented - namely, those concerned with improving communications between doctors in hospital and in general practice, and improving communications with patients. Respondents were more pessimistic about the prospects of implementing the recommendations than about their importance. Respondents thought that standards were important for improving care, and half would stop payments to general practice diabetic clinics that did not keep to district standards for diabetes care. For two recommendations a mismatch occurred between the importance of the recommendations and likelihood of implementation. This may reflect the practical problems of implementing recommendations. 18 of the 22 respondents thought that the study was useful in generating recommendations.

Conclusions-The Delphi technique is a useful method for determining priorities for diabetes care and in assessing the feasibility of implementing recommendations.

(Quality in Health Care 1996;5:3-8)
Keywords: diabetes care, policy priorities, Delphi study.

\section{Introduction}

Research in isolation is of limited value unless the established benefits can be translated into common practice. Currently publication and presentation of results are too often seen as ends in themselves. Thereafter, it is left to opinion formers and others to embrace and implement innovations. ${ }^{1}$

The problems associated with implementing research findings have been discussed recently. ${ }^{2} 3$ Several methods have been adopted which aid the transfer of research results into clinical practice. ${ }^{45}$ These include peer review, ${ }^{6}$ consensus conferences, ${ }^{67}$ and the use of the modified Delphi technique. ${ }^{8}$ A common feature of these approaches is that a group of experienced practitioners review the available medical literature and judge the appropriäteness of a particular form of action.

From three related pieces of research conducted earlier we wanted to develop a consensus on which recommendations were the most important and most likely to be implemented. The first part of that research had used nominal groups to identify patients' and professionals' views about priorities for care of diabetes. ${ }^{9} 10$ This had been followed up by a series of in depth interviews which helped us to ascertain patients' concerns about diabetes care. The last part was a postal survey of diabetic patients in South Tyneside. Table 1 shows these findings collected together as an unpublished draft report.

We could have produced our own recommendations without recourse to outside involvement, or held face to face meetings with local patients and healthcare professionals to consider the practical implications of the study. We wanted, however, to minimise any interactional difficulties which might discourage or inhibit group members from contributing fully and wished to involve "experts" in diabetes from outside the locality. Hence, we decided to use the Delphi technique. ${ }^{11}$

The advantages of this technique are well known. ${ }^{12}$ It is a useful way of producing a consensus on a subject or allowing a full understanding of opposing perspectives. ${ }^{911}$ It is particularly useful for involving people who cannot meet, provides some anonymity for individual respondents, ${ }^{12}$ avoids the social pressures that can exist within groups to conform, and can produce many ideas. ${ }^{11}$

The Delphi technique is increasingly used in healthcare research ${ }^{9}$ and has been used to determine priorities in at least four areas: health authority spending, ${ }^{13}$ nursing research, ${ }^{14}$ 
Table 1 Summary of draft report on determining priorities in diabetes care for patients

\begin{tabular}{|c|c|c|}
\hline Method & Analysis & Findings \\
\hline $\begin{array}{l}\text { A structured group } \\
\text { process called } \\
\text { "nominal group } \\
\text { technique" was used } \\
\text { to identify patients' } \\
\text { and professionals' } \\
\text { priorities for } \\
\text { diabetes care }\end{array}$ & $\begin{array}{l}\text { Content analysis of group } \\
\text { discussions and findings, and } \\
\text { by group and individual } \\
\text { rankings and weightings of } \\
\text { priorities }\end{array}$ & $\begin{array}{l}\text { Patients and professionals agreed the following to be important: } \\
\text { - Information given to patients should be easy to understand, consistent, } \\
\text { and explain diabetes and its complications } \\
\text { - Interactions between the patient and doctor - the patient being able to } \\
\text { talk to the doctor, the patient being listened to, and cooperation and } \\
\text { communication between professionals } \\
\text { - Patient autonomy - including having the opportunity to discuss results } \\
\text { and suggest changes in treatment }\end{array}$ \\
\hline \multirow{3}{*}{$\begin{array}{l}3 \text { patient and } 3 \\
\text { professional groups }\end{array}$} & & $\begin{array}{l}\text { - Easier access to the doctor, with short waits in hospital and better } \\
\text { transport to care }\end{array}$ \\
\hline & & $\begin{array}{l}\text { Professionals highlighted: } \\
\text { - Continuity of the professional relationship with supportive, receptive, and } \\
\text { empathetic professionals }\end{array}$ \\
\hline & & $\begin{array}{l}\text { Patients emphasised: } \\
\text { The desire to know enough to live a normal life } \\
\text { - More emphasis on explaining diabetes and its complications particularly } \\
\text { on diagnosis }\end{array}$ \\
\hline $\begin{array}{l}\text { Unstructured } \\
\text { interviews with } 28 \\
\text { diabetic patients }\end{array}$ & $\begin{array}{l}\text { Ground theory method. } \\
\text { Transcripts were coded using } \\
\text { ethnographic software. Data } \\
\text { were analysed to provide } \\
\text { theories and concepts about } \\
\text { patients' views and } \\
\text { experience of diabetes care }\end{array}$ & $\begin{array}{l}\text { Patients needs are related to their "diabetes career:" their past experience } \\
\text { and adaptations, and current experience of their condition. They may also } \\
\text { develop specific concerns, which are dependent on the stage of the } \\
\text { condition and the presence or absence of complications. } \\
\text { Patients were dissatisfied with the failure of professionals and diabetes } \\
\text { services to respond to their concerns about the changes in the effects of } \\
\text { diabetes over time. }\end{array}$ \\
\hline $\begin{array}{l}\text { Postal questionnaire } \\
\text { survey of } 458 \text { people } \\
\text { with diabetes }\end{array}$ & $\begin{array}{l}\text { Statistical tests for } \\
\text { significance, principal } \\
\text { component analysis, and } \\
\text { logistic regression }\end{array}$ & $\begin{array}{l}\text { Patients with complications were more likely to be dissatisfied with } \\
\text { professionals than other patients. } \\
\text { Half of patients reported that they had not seen a chiropodist in the past } \\
\text { year. }\end{array}$ \\
\hline
\end{tabular}

outcomes in primary care, ${ }^{15}$ and treatment outcomes in mental health. ${ }^{16}$ In these examples the Delphi survey has produced ideas from an expert panel without recourse to the medical literature. There are no examples of its use to determine priorities from, or the feasibility of implementing, a single piece of research.

\section{Methods}

We used a variant of the Delphi technique which has been used to examine policy issues. ${ }^{12}$ The Delphi technique is defined as "a method of systematic solicitation and collation of the informed judgement on a particular topic."12 The procedure used three carefully designed sequential questionnaires interspersed with summarised information and opinions with feedback from earlier responses. In a policy Delphi, priorities are established, but importantly the group also consider the question of political feasibility. ${ }^{12}$

\section{PARTICIPANTS}

The original research was supported by diabetic patients, general practitioners, the local hospital, the family health services authority, the Community Health Council, and the British Diabetic Association in South Tyneside. During the design, development, and conduct of the research the project had a high profile locally, particularly among diabetic patients, and healthcare professionals and managers. It was therefore logical and important to include these people in setting priorities for care. Participants were selected if they met one or more of the following criteria:

- They were involved in providing or purchasing diabetes services: purchasers included members from the local purchasing consortium and fundholding general practitioners

- They were recognised as decision makers or opinion formers

- They were knowledgeable about diabetes or had experience of diabetes health education
- They were familiar with our research or allied research.

All participants were people who had a fairly high level of responsibility in their area of expertise. They included patients with diabetes, consultant diabetologists, general practitioners, diabetes researchers, a practice nurse, a community diabetic nurse, chiropodists, public health doctors, consumer groups, and health service managers. Half of the participants were known to members of the monitoring team. The rest were recruited by the researcher on the recommendation of other participants. Most of the participants (21/28) were from Tyneside. Although this was primarily a local initiative designed to involve and influence local policy makers, we thought that contributions from nationally recognised experts and organisations would give a different perspective as well as adding weight to our panel. Hence seven participants were from other parts of the United Kingdom.

DELPHI SURVEY - FIRST ROUND

All respondents were contacted by the researcher by telephone to check their availability during the study time. Respondents were sent a letter reiterating the purpose of the study together with a copy of the draft report, which included a summary of the draft report and a questionnaire in which they were invited to list as many recommendations as possible in response to a single question. The question was:

"From results contained in this report what recommendations would you make to improve the care of people with diabetes?"

Non-respondents were contacted by telephone and a reminder letter. A code was included in both rounds of the questionnaire to identify non-respondents. Respondents were reassured that all contributors would remain anonymous. 
The recommendations produced were typed on index cards and circulated to the monitoring team made up of the three authors. Each member looked for similarity of response to reduce the recommendations to more manageable numbers. The monitoring team tried not to misrepresent or distort the information provided in reducing the initial responses. Recommendations that did not seem to derive from the findings contained in the report were included if they were designed to improve diabetes care.

\section{DELPHI SURVEY - SECOND ROUND}

In the next round each respondent received background information on the nature and organisation of diabetes care in South Tyneside. This information was important for participants to judge the practicability of implementing their recommendations. No information was provided about the current or future financing of diabetes care. They were also asked to review the summary of recommendations and independently rate each item on two 5 point Likert scales - how important the recommendation is to improving diabetes care, and how likely the recommendation is to be introduced in the next five years. These scales were based on those recommended and used by Turoff for a policy Delphi. ${ }^{12}$ An example question is given in the box. Respondents were also asked for written comments on any of the recommendations.

\section{PARTICIPANTS' RESPONSES TO THE SECOND} ROUND FINDINGS

The scores for the second round were collated by the monitoring team into frequencies. Each participant was sent a list of the frequencies for each recommendation, together with a sample of comments and a brief discussion by the monitoring team. Space was provided for unstructured written comments on the value of the Delphi exercise.

\section{Results}

FIRST ROUND

Twenty eight people were recruited to the first round. Of these, 20 respondents produced 180 separate recommendations. The monitoring

\section{Sample question \\ Question 5}

Please indicate a relative judgement on two scales, both from 1 to 5 , for each of the recommendations listed. The first scale asks you to indicate how likely you feel each recommendation is to be put into practice in the next five years. The second scale asks you to indicate how important you feel each recommendation is to improving the diabetic care service. Please circle the number between 1 and 5 which best reflects your own judgement.

Target educational packages, information and support to priority times:

(a) For newly diagnosed patients

(b) When there are changes in treatment

(c) With the onset of complications

$\begin{array}{lllllll}\text { Highly unlikely } & 1 & 2 & 3 & 4 & 5 & \text { Highly likely }\end{array}$ $\begin{array}{lllllll}\text { Very important } & 1 & 2 & 3 & 4 & 5 & \text { Very important }\end{array}$ team reduced these to 28 summary recommendations.

\section{SECOND ROUND}

Twenty two of 28 respondents completed the second round questionnaire. The two respondents not in the first round had submitted their responses to the first questionnaire too late for them to be included in the second questionnaire, but they took part in the second round voting.

The recommendations produced by respondents were ranked on the how important and how likely to be implemented scales (table 2). Several of the recommendations on the two scales have identical votes to other items; their place on the rank is determined by which has the maximum number of " 5 " votes, then " 4 " votes, then " 3 " votes, etc.

There was considerable consensus about the recommendations that were important and most likely to be put into practice. For example, four of the top six most important recommendations $(1,2,3$, and 6$)$ also ranked in the top seven for likely to be put into practice (fourth, first, sixth, and seventh, respectively). These recommendations are concerned with communication between doctors in hospital and in the community and with communication with patients. Indeed, 19 of the 28 recommendations can be classified as being about patient and professional communication.

Overall, respondents were more pessimistic about the prospects of implementing the recommendations than about how important a recommendation was. For example, 17 of the recommendations scored over $80 \%$ on the importance scale, but only one of the recommendations scored $80 \%$ or more on the likely to be put into practice scale.

Some recommendations developed the findings in the draft report. For example, recommendations 2,10 , and 25 were three different responses to the finding in the report that patients want more support at "priority times" - at the time of diagnosis, when there are changes in treatment, and when complications ensue. The three recommendations received different levels of support from respondents. All respondents (21/21) thought that targeting educational packages is important, but only $81 \%(17 / 21)$ were optimistic about this becoming a reality. Respondents also scored assessing patients' needs and agendas at priority times as important $(20 / 22)$ but only $41 \%(9 / 22)$ thought that it would happen. A specific suggestion of developing educational videos for use at priority times attracted even less support from respondents, as only $45 \%(10 / 22)$ scored it as important and $27 \%(6 / 22)$ thought that it would be put into practice.

Respondents thought that locally produced standards are important (recommendations 5 and 12) but only half of them (11/22) supported the ending of payments to general practice clinics that do not adhere to the districts standards for diabetes (recommendation 7 ), and only $23 \%(5 / 22)$ supported a ban on staff providing care if they do not participate 
Table 2 Recommendations ranked by respondents' votes on two scales; "how important" to improving diabetes care, and "how likely to be put into practice" in next five years

\begin{tabular}{|c|c|c|c|c|}
\hline \multicolumn{2}{|c|}{ Recommendation } & \multirow{2}{*}{$\begin{array}{l}\text { How important to } \\
\text { improving health } \\
\text { care, scores of } 5 \text { or } \\
4 \text { (Frequency (\%)) } \\
21 / 21\end{array}$} & \multirow{2}{*}{$\begin{array}{l}\text { How likely to be } \\
\text { put into practice in } \\
\text { next five years } \\
\text { (Combined rank } \\
\text { from 1st to 28th) } \\
4\end{array}$} & \multirow{2}{*}{$\begin{array}{l}\text { How likely to be } \\
\text { put into practice in } \\
\text { next fice vears, } \\
\text { scores of } 5 \text { or } 4 \\
\text { (Frequency }(\%) \text { ) } \\
15 / 22(68)\end{array}$} \\
\hline 1 & $\begin{array}{l}\text { Ensure that advice/information given to patients by general } \\
\text { practitioners and hospitals is clear and consistent }\end{array}$ & & & \\
\hline 2 & $\begin{array}{l}\text { Target educational packages, information, and support to priority } \\
\text { times: } \\
\text { Newly diagnosed patients } \\
\text { When there are changes in treatment } \\
\text { With the onset of complications }\end{array}$ & $21 / 21$ & 1 & $17 / 21(81)$ \\
\hline 3 & $\begin{array}{l}\text { Increased cooperation and communication among professionals, } \\
\text { especially between hospitals and general practice }\end{array}$ & $22 / 22$ & 6 & $14 / 22(64)$ \\
\hline 4 & $\begin{array}{l}\text { Increased access and availability to chiropody services for people } \\
\text { with diabetes }\end{array}$ & $22 / 22$ & 13 & $10 / 21(48)$ \\
\hline 5 & $\begin{array}{l}\text { Development of shared objectives for diabetes care between } \\
\text { hospital and general practice }\end{array}$ & $22 / 22$ & 9 & $13 / 22(59)$ \\
\hline 6 & $\begin{array}{l}\text { Patients should be given the opportunity to discuss their results } \\
\text { and changes in treatment with doctors }\end{array}$ & $22 / 22$ & $i$ & $13 / 22(59)$ \\
\hline 7 & $\begin{array}{l}\text { Family health services authority should be encouraged to only } \\
\text { provide disease management clinic payments to those general } \\
\text { practice clinics that adhere to the district's standards }\end{array}$ & $21 / 22(95)$ & 12 & $11 / 22(50)$ \\
\hline 8 & $\begin{array}{l}\text { Involve family and carers and people with diabetes in education } \\
\text { and support }\end{array}$ & $21 / 22(95)$ & 3 & $15 / 22(68)$ \\
\hline 9 & Increased diabetic liaison nurse sessions & $21 / 22(95)$ & 14 & $10 / 21(48)$ \\
\hline 10 & $\begin{array}{l}\text { Patients needs and agendas should be assessed regularly } \\
\text { throughout their "diabetic career" but particularly for: } \\
\text { Newly diagnosed patients } \\
\text { When there are changes in treatment } \\
\text { With the onset of complications }\end{array}$ & $20 / 22(91)$ & 16 & $9 / 22(41)$ \\
\hline 11 & $\begin{array}{l}\text { Make education, information sessions, and communication more } \\
\text { patient centred }\end{array}$ & $20 / 22(91)$ & 5 & $14 / 22(64)$ \\
\hline 12 & $\begin{array}{l}\text { There should be locally developed standards of care based on the } \\
\text { principles of the British Diabetic Association Charter and St } \\
\text { Vincent's Declaration }\end{array}$ & $20 / 22(91)$ & 8 & $13 / 22(59)$ \\
\hline 13 & $\begin{array}{l}\text { Each centre of diabetes care should provide an open access service, } \\
\text { at stated times during the week, for patients and carers who want } \\
\text { advice in person or over the telephone }\end{array}$ & $20 / 22(91)$ & 10 & $12 / 22(55)$ \\
\hline 14 & Clarification of the role of the diabetic liaison nurse & $19 / 22(86)$ & 2 & $17 / 22(77)$ \\
\hline 15 & $\begin{array}{l}\text { Increased patient involvement in the development and design of } \\
\text { information and methods of communication }\end{array}$ & $19 / 22(86)$ & 17 & $8 / 22(36)$ \\
\hline 16 & $\begin{array}{l}\text { Give training to all professionals in listening, communication, and } \\
\text { counselling skills }\end{array}$ & $18 / 22(81)$ & 22 & $6 / 22(27)$ \\
\hline 17 & $\begin{array}{l}\text { Only clinic staff who participate in regular education or training } \\
\text { should be allowed to provide diabetes care }\end{array}$ & $18 / 22(81)$ & 24 & $5 / 22(23)$ \\
\hline 18 & $\begin{array}{l}\text { Provide sufficient funds to establish a diabetes resource centre } \\
\text { which aims to provide holistic diabetes care. The centre would be } \\
\text { staffed by a chiropodist, dietician, doctor, diabetic nurse, diabetes } \\
\text { educator, exercise consultant, etc }\end{array}$ & $17 / 22(77)$ & 23 & $5 / 21(24)$ \\
\hline 19 & $\begin{array}{l}\text { Provide an interpreter/link worker/bilingual worker to explain } \\
\text { information to patients whose first language is not English }\end{array}$ & $17 / 22(77)$ & 19 & $7 / 22(32)$ \\
\hline 20 & $\begin{array}{l}\text { Give patients a clear choice of where they wish to attend for } \\
\text { diabetes care (hospital, general practitioner, or shared care) }\end{array}$ & $17 / 22(77)$ & 11 & $11 / 22(50)$ \\
\hline 21 & Provide more group education sessions in South Tyneside & $15 / 22(68)$ & 18 & $8 / 22(36)$ \\
\hline 22 & Train all professionals in patient centred consultation techniques & $14 / 22(64)$ & 27 & $3 / 22(14)$ \\
\hline 23 & $\begin{array}{l}\text { Review of current provision of waiting times at clinics with } \\
\text { particular reference to: } \\
\text { A clearly defined waiting time for first and subsequent } \\
\text { appointments } \\
\text { A clearly defined standard for waiting times at clinics } \\
\text { Audit of waiting times } \\
\text { Patient's charter standards } \\
\text { Accessible locations in the community }\end{array}$ & $13 / 21(62)$ & 15 & $9 / 21(43)$ \\
\hline 24 & $\begin{array}{l}\text { The key provider of diabetes care in South Tyneside will be the } \\
\text { newly established diabetes resource centre }\end{array}$ & $10 / 22(45)$ & 20 & $6 / 22(27)$ \\
\hline 25 & $\begin{array}{l}\text { Develop educational videos for use in clinics or the patients home, } \\
\text { covering: } \\
\text { Newly diagnosed patients } \\
\text { Changes in treatment } \\
\text { The onset of complications }\end{array}$ & $10 / 22(45)$ & 21 & $6 / 22(27)$ \\
\hline 26 & $\begin{array}{l}\text { Create a new post of diabetes educator who would be trained in } \\
\text { adult education and have no clinical responsibility }\end{array}$ & $10 / 22(45)$ & 28 & $1 / 20(5)$ \\
\hline 27 & $\begin{array}{l}\text { Provide a "buddy" system for newly diagnosed patients to share } \\
\text { experiences and anxieties }\end{array}$ & $9 / 22(41)$ & 25 & $5 / 22(23)$ \\
\hline 28 & Decrease educational input and support at non-priority times & $2 / 22(9)$ & 26 & $4 / 22(18)$ \\
\hline
\end{tabular}

in regular education and training on diabetes (recommendation 17).

For some recommendations there was a mismatch between the scores for the importance of the recommendation and the scores for the likelihood of it being put into practice. For example, respondents voted increased availability of chiropody services into fourth on the importance scale but only 13th on the likely to be put into practice scale. Conversely, clarifying the role of the diabetic liaison nurse was voted the 14 th most important recommendation but the second most likely to be implemented.
PARTICIPANTS' RESPONSES TO THE SECOND) ROUND FINDINGS

Respondents were asked to participate in a time consuming activity and to digest a fairly lengthy and technical report, yet were generally positive about the value of this Delphi study in generating recommendations from research. Eighteen of the $22(81 \%)$ respondents who took part in the study agreed that it was useful in generating recommendations.

The perceived benefits were in three main areas. Firstly, participants saw that this was a way in which patients could safely participate. One respondent commented, "... anything 
which allows the patient to participate in a study which may affect his or her illness in the future is of utmost importance." Secondly, participants also appreciated the collaborative element of the study, "It attempted to marry the views of experts and those of patients to develop an improved service for patients with diabetes." Lastly, participants considered that it "generated a wide range of ideas" which could be safely aired without fear of hostility.

\section{Discussion}

There was a high degree of consensus by respondents about those recommendations considered to be important and likely to be put into practice. Respondents were more pessimistic about the prospects of implementing recommendations than about how important the recommendations were to improving diabetes care.

The Delphi technique is not without its critics. It is important that its ability to produce a convergence and consensus of opinion on a given topic should be viewed with caution. ${ }^{17}$ There is a danger in trying to produce consensus and so ignoring dissenting contributions. It is argued that because the natural tendancy of a Delphi survey, especially over several rounds, is to centralise opinion, that dissenting distributions should be viewed with special interest. Doing this has been shown to make more use of the information and to allow areas of agreement and disagreement to be identified. ${ }^{12} 18$ In our survey space was provided for respondents to disagree and to give reasons for their choices. Despite this few respondents made comments. This may be because, unlike a conventional Delphi in which participants generate ideas from their own experience, research findings were the starting point, which may have reduced the number of dissenting comments.

A crucial element of Delphi is the selection of participants. ${ }^{19}$ Grimshaw has pointed out that the Delphi technique has poor reliability between panels and different groups of participants will produce different recommendations. ${ }^{5}$ By selecting interested and enthusiastic participants there is a danger that they have produced recommendations which are unrealistic for South Tyneside. Further research is needed to find how the identification and composition of such panels influence recommendations.

Other important sources of potential problems are the composition and activities of the monitoring team. Charlton has described the fact that "consensus methods can be perverted into a mask for professional self-interest, a disguise for intra-professional power struggles..., or may be hijacked by outside interest groups." 20 Much depends on who initiates, designs, and conducts the consensus exercise. Inevitably, participants bring their own interests and agendas to the consensus method, and at some stage they have to make arbitrary decisions to produce consensus. The best that can be done is to make the consensus process explicit and leave the judgement of that to others. ${ }^{21}$ As far as possible we have done that.
The main practical problem was keeping the participants to the deadlines set by the research team. All participants had numerous professional responsibilities, and the survey was conducted at the end of the summer holidays. The recruitment and contact by the research associate, usually by telephone, was an important element in achieving a high response rate, and in maintaining the respondents' interest in the study. It is important that participants should be highly motivated as other people are not present to stimulate and maintain motivation. There are also no opportunities for verbal clarification or social interaction, which people value.

The mismatch between scores on the how important scale and scores on the how likely to be implemented scale is interesting. Two examples are increased availability of chiropody services, and clarifying the role of the diabetic liaison nurse. The first example, which is considered to be important but not likely to be implemented, may reflect realism about the prospects of obtaining additional financial support to deploy more chiropodists. The second example, which is not considered to be important but is likely to be implemented, may illustrate the fact that there are few resource consequences of trying to clarify someone's role.

The mismatch between respondents' recommendations for importance and likelihood of being put into practice was highlighted by one respondent: "I am amazed at how pessimistic this group of 'experts' is about the possibility of achieving highly desired outcome. Realism is important, resources are tight but there is a big mismatch between the things agreed as important and the belief that they can be achieved, even in areas I suspect are directly under the influence of these same experts!"

Respondents suggested the development of standards and the imposition of sanctions as ways of improving diabetes care. These were not directly referred to in the report, but clearly some respondents thought that they were important for achieving better care, including better communications. The voting showed that respondents thought that locally produced standards were important and that half of the respondents supported the end of payments to general practice diabetes clinics that do not adhere to district standards.

Delphi seems to be useful in generating a consensus and also in determining the feasibility of implementing actions. Turoff sees the policy Delphi as useful for establishing the different positions that participants advocate, together with identifying the main arguments for and against. ${ }^{12} \mathrm{He}$ argues that it should be seen as a tool for policy analysis rather than for policy decision making. Also, the policy Delphi can be seen as a way of forewarning commissioning bodies of the arguments that they will face. We view our own findings as an adjunct to established local mechanisms for considering policy.

The contribution of patients and their carers to discussions about the quality of provision 
and purchasing is undervalued. Patients think that they are good judges of quality of care, ${ }^{22}$ but little attention has been paid to methods that are appropriate for canvassing patients' views about the commissioning and monitoring of services. ${ }^{23}$ Among our panel of experts we had three patients and three patients' representatives, who make up over a quarter of respondents. The Delphi survey may be a useful way of involving consumers in deciding on priorities of clinical care in other areas of medicine. ${ }^{1213}$ Delphi participants value the ability to contribute and yet remain anonymous, which may be particularly important for patients, who might have to fight to be heard in a consensus setting group.

We think that the Delphi technique is a useful way of involving healthcare professionals and patients in developing recommendations which can influence local policy. It offers one way of translating research findings into action.

This project was funded by the Department of Health. We also acknowledge the help of the panel members, who included: William $F$ Worth, chief executive, South of Tyne Health Commission; John $\mathrm{R}$ Robson, head of Department of Chiropody, South Tyneside Health Care Trust; Alethea Foster chief podiatrist, Kings College Hospital London; Brigid Marron, diabetest, Kings College Cospital, London; Brigid Marron, diabetes specialist nurse, Hebburn Health Centre; Tim Hares, research worker, Save The Children; Susan Dobinson, acting district dietician, South Tyneside Health Care Trust; Patricia Thompson, practice nurse, Gibson Court Health Centre, South Shields, Professor K G M M Alberti, director of research and development, Northern Regional Health Authority; Dr C Waine, director of primary care, Sunderland Health Commission; Dr Susan $\mathrm{H}$ Roberts, consultant physician Preston Hospital, North Tyneside; Dr John Parr, consultant physician, South Tyneside District Hospital. (Not all participants wished to be identified.) Dr Jeremy Grimshaw provided help with the manuscript, Maureen Duffy researched the literature, and Theresa Huddart gave secretarial support.

1 Anonymous. Does research make for better doctors [Editorial]? Lancet 1993;342:1063-4.
Haines A, Jones R. Implementing findings of research. $B M 7$ 1994;308:1488-92.

3 Jones R, Spencer J. Conference report: teaching old docs new tricks: research dissemination and professional benew tricks: research dissemination and profe

4 Russell I, Grimshaw J, Wilson B. Scientific and methodological issues in quality assurance. Proceedings of the Roval Society of Edinburgh 1993;1018:77-103.

5 Grimshaw J, Wallace S, Russell I. Towards a scientific basis for clinical guidelines. Metodologia and Didattica Clinica 2:109-19.

6 Grol R, Mokkink H, Schellevis F. The effects of peer review in general practice. $\mathcal{F} R$ Coll Gen Pract 1988;38:10-3.

7 Lomas J, Anderson G, Enkin M, et al. The role of evidence in the consensus process: results from a Canadian consensus exercise. $7 A M A$ 1988;259:3001-5.

8 Brook RH. Practice guidelines and practising medicine. Are the

9 Gallagher M, Hares T, Spencer J, Bradshaw C, Webb I. The nominal group technique: a research tool for general practice? Fam Pract 1993;10:76-81.

10 Hares T, Spencer J, Gallagher M, Bradshaw C, Webb I. Diabetes care: who are the experts? Quality in Health Car 1992;1:219-24.

11 Linstone H, Turoff $\mathrm{M}$, eds. The Delphi method: techniques and applications. Massachusetts: Addison-Weslev, 1975.

12 Turoff $M$. The design of a policy Delphi. Technological Forecasting and Social Change 1970;2:149-71.

13 Charlton JRH, Patrick DL, Matthews G, et al. Spending priorities in Kent: a Delphi study. 7 Epidemiol Community Health 1981;35:288-92.

14 Bond S, Bond J. A Delphi survey of clinical nursing research priorities. $\mathcal{F}$ Adv Nurs 1982;7:565-75.

15 Hutchinson A, Fowler P. Outcome measures for primary care: what are the research priorities? Brf Gen Pract 1992; 42:227-31.

16 Clark A, Friedman MJ. The relative importance of treatment outcomes. A Delphi group weighting in menta health. Evaluation Review 1982;6:79-93.

17 Goodman CM. The Delphi technique: a critique. $\mathcal{F} A d$ Nurs 1987;12:729-34.

18 Scheibe M, Skutsch M, Schofer J. Experiments in Delphi methodology. In: Linstone H, Turoff M, eds. The Delphi method: techniques and applications. London: AddisonWesley, 1975

19 Delbecq AL, Van de Ven AH, Gustafson DH. Group techniques for programme planing: a guide to nominal group and Delphi processes. Glenview, Illinois: Scott Foresman, 1975.

20 Charlton BG. Practice guidelines and practical judgement: the role of mega-trials, meta-analysis, and consensus. $B$ the role of mega-trials, me

$21 \mathrm{Grol} \mathrm{R}$. Development of guidelines for general practice. $\mathrm{Br}$ f Gen Pract 1993;43:146-51

22 Irvine D. Managing for quality in general practice. London Kings Fund Centre, 1990

23 Joule N. Involving users of health care services: moving beyond lip service. Qualitv in Health Care 1993;2:211-2. 